\title{
INVESTIGATING THE IMPACT OF CEO'S SOCIAL NETWORK ON SME PERFORMANCE AND ACCESS TO EXTERNAL RESOURCES IN THE MOROCCAN TEXTILE INDUSTRY
}

Tahirou Younoussi Meda Adama University of Tahoua, Republic of Niger E-mail: tahirouyounoussi@gmail.com

Mohammed Nadif

University Mohammed V, Morocco E-mail: mohamednadif@yahoo.fr

Submission: $11 / 05 / 2017$ Accept: 12/06/2017

\section{ABSTRACT}

This paper analyses the relationship between the social network dimensions, the performance of Moroccan SMEs of the textile industry and their access to external resources. As these companies face a fierce competition in recent years, their CEOs' social networks are playing a significant role in their success and survival. Through a sample of 112 SMEs and a quantitative method, our results show that the more the network is important, the more it promotes SME performance and access to information resources, that having closer tie with the bankers allows a better access to financial resources, that knowing and having links with people in high places is a privilege and contributes effectively to an organizational performance.

Keywords: social network, SME CEOs, textile industry, resources, performance 
DOI: 10.14807/ijmp.v9i1.670

\section{INTRODUCTION}

There is a recurring observation on SMEs: they lack resources. Whether in terms of human, financial or other resources, SMEs, by their size, are limited in their means of action. It is difficult for them to invest in new equipment, to hire staff, to launch ambitious communication campaigns. How can they compete internationally with the world's largest companies? Their ability to seize opportunities in terms of markets would be closely linked to their ability to connect to the networks around them.

These networks can be institutionalized and formal such as inter-firm cooperation, or informal networks such as personal networks (McEVILY; ZAHEER, 1999). But the notion of social network is generally related to the notion of community in the sense that the network appears as a group of individuals united by frequent social relations which link them to a community.

The literature on social networks has developed a very rich reflection on the necessary conditions required for a personal network to provide a maximum of information. The discussion on the concept focused on three distinct dimensions as stated by SEIBERT et al. (2001). The first is the content of links (GRANOVETTER, 1973). Some executives have a portfolio dominated by weak ties, others by strong ties. The second is the network structure (BURT, 1992).

Some CEOs have in their personal network many structural holes (i.e. knowing people who do not know each other), others have rather dense networks. Finally, the third dimension concerns the people attributes in the personal relationships portfolio (LIN, 1999).

CEOs may have links with people who are relatively close to them on various criteria (technical field, geographical position, etc.) and some of them are family members, friends and acquaintances, business and professional partners, consultants etc. Their help and support are essential to accomplish certain tasks or achieve objectives that the CEO could not have achieved individually.

In Morroco for example, even the creation, integration or success of a business depends on the manager's social network including special relations with the business community. Given its importance in the society, personal relations are 
used at all levels of economic activity especially by the SMEs CEOs who customize the way business works.

Despite the abundance of literature on the subject, critical gap remains. Few studies have looked into the diversity of social contexts faced by the managers (FANG et al 2012, SURIN et al 2015). Some aspects of its use in others countries have not yet been studied and there is still a lack of agreement on how to define and mesure it (DOH; ZOLNIK, 2011).

In the Moroccan's textile industry, most of the CEOs assume almost exclusively administrative, financial and social activities and participates actively in the daily business management (TANGEAOUI, 1993). This omnipresence in the company's management can explain why their relational networks often identify with those of the company.

But as shown by the recent economic crisis, the most vulnerable and most affected SMEs were those in the textile industry. So the aim of this study is to analyze the real impact of social network on these SMEs access to external resources and performance. It hopes to provide more ideas and insights, on whether managers who have greater social network are the most successful and have better access to external resources and if some relations promotes more performance or facilitate more access to external resources than others.

\section{MATERIAL AND METHODES}

\subsection{Moroccan SMEs of the textile industry}

The data obtained from the Ministry of Commerce and Industry for 2009 indicate that the textile industry occupies a prominent position in the Moroccan economy and contribute up to $42 \%$ and $34 \%$ respectively in employment and manufacturing exports. More than 700 organizations operate in this industry approximately $22 \%$ of all industrial units and generate $13 \%$ of production, $17 \%$ of the value added and $14 \%$ of manufacturing investment.

Most of them are SMEs with a lack of significant resources and a strong centralized management. The difficulty of integrating new technologies, low commitment to research and development impede the innovation process in these companies. They have many characteristics that suggest that the use of social network has been very important in recent years. 
Since 2008, most of them are experiencing difficult situations due to the financial crisis, the short duration of subcontracted contracts and the increased competition with the entry of new competitors (Chinese and European in particular). These factors force them to be limited to certain strategic options and use their relational networks.

They added more social network in the companies' performance and sustainability strategy. Many CEOS are founders or owners with a much larger role in the technical and operational activities of these companies. They assume exclusively administrative, financial and social responsibilities and get involved in the daily management efforts. Through their relationships with stakeholders, the company gets its first clients, obtains information about the competition, access to new markets and provides the funds it needs.

\subsection{CEO's Social network}

According to FENG et al, (2012), social network, broadly understood as a group of people linked by a set of relationships, is a well-established area in the fields of socioeconomics. It can be described as the set of interpersonal relationships that an individual possesses which allow him to construct his everyday social environment, both personally and professionally (BRASSIER-RODRIGUES; BRASSIER, 2009).

A network is defined by Aldrich and Zimmer, (1986) as the set of people connected by a certain type of relationship and constructed by identifying the links between each person in the studied population. Four dimensions are identified by the authors: density, connectivity, centrality and link strength.

Johannisson, (1986) also considers that the network consists of the only people on whom the entrepreneur builds his business (suppliers and clients, former colleagues or partners, etc.) and not all potential sources of people on the territory. In his arguments, the network is personal.

but, Dubini and Aldrich (1991) show the link between these two levels of analysis. They define a personal network as "All persons with whom the entrepreneur has direct relations or, in some cases, indirect relationships through direct relations". 
INDEPENDENT JOURNAL OF MANAGEMENT \& PRODUCTION (IJM\&P)

http://www.ijmp.jor.br

v. 9, n. 1, January - March 2018

ISSN: 2236-269X

DOI: 10.14807/ijmp.v9i1.670

According to them, the simplest kind of personal network includes the direct links that connects the entrepreneur to the people with whom he has direct exchanges. They are people with whom the entrepreneur meets face to face and from whom he obtains services, advice and moral support". The "extended" network can be the collective result of personal interconnected networks.

This involves within a company, relations between CEOs, managers and employees when they are structured by forms of coordination and control. Between companies, it is the relationship between the members of these companies when they develop social relationships.

The CEO can engage his company in a partnership or cooperation with another company to develop its activities. When his company lack of resources, he can be a member of an organized network such as an association which can promote his products or help him to find customers.

Therefore, CEO's social network can be considered as a web of connections developed from past service of the CEO in executive, director, and similar senior positions at other firms, alumni educational network associations, and social clubs (GRIFFINS et al 2016; MIZRUCHI, 1996).

It can provide strategic value to firms through the connection with other organization by reducing the uncertainty associated with obtaining the external resources (FALEYE et al, 2014). It can grows in size and produce net benefits for the CEO that can change decision-making.

What is the importance of a CEO's social network? According to Reynolds (1991), the main evidence of the importance of social networks is that most CEOs create their business at home, in a geographical context and the same community. This allows them to have multiple contacts to find funds, suppliers, customers, etc. This also reduces the risk associated with the business creation. Thus, by creating in familiar contexts, the CEO can get the maximum amount of useful information and does not take the risk to be vulnerable.

What are effects of a CEO's network? The personal network in which the CEO is inserted has effects throughout the entrepreneurial process (BRUDERL; PREISENDORFER, 1998). It plays a role in engaging in the entrepreneurial act (network founding hypothesis) but also in its success (network success hypothesis). 
It also offers the necessary support for the managerial challenge to reconfigure the firm so that it can exploit the fruits of its innovation (KRISHMAIER; STATHOPOULOS, 2008). In addition, CEO's network offers opportunities, push sales and leads to organizational performance. It affects both the board composition and corporate governance policies.

The connection between the CEO's social network and SME performance

Performance has always been a controversial issue because of the large number of conceptual models proposed in the literature and the many meanings developed around this concept. It varies considerably from one organization to another and from one context to another (LUTHANS; STEWART, 1977; BAMBERGER, 1979).

But this "contingent" and "multidimensional" nature of performance applies to all organizations including SMEs whose primary objectives (sustainability, independence...) are not the same as those of large firms (growth, international development...).

As noted by Pennings and Goodman (1977), three elements characterize SME performance. The first refers to the "constraints" and represent the requirements that SMEs must meet. Any failure to meet them leads to the inability to perform. The second concerns the "objectives", they are future states desired by the CEO (BAMGERGER, 1979) on the basis of which he sets his evaluation criteria.

Finally, the third are normative standards from which it can be considered if an SME is performing. They indicate scales measurement performance as evaluated by SME CEOS. Therefore, it can be considered that SME performance takes into account its own characteristics and highlights the central role of the CEO. Many works shows the crucial impact of the manager on the performance of its business. For example, Alizadeh (2000) classifies work on the role of the CEO in the success of the company into two main approaches: the individualistic and social approach.

In the individualistic approach, SME performance is explained by some demographic, psychological and behavioral characteristics of the CEO, his leadership skills and technical know-how etc. The social approach which was also developed by ALDRICH \& DUBINI, (1991), ALDRICH \& ZIMMER (1986) focuses on 
the social and relational environment of the company and the networking activities of its manager.

If the managers have more contact, it will be less difficult for them to find, select and retain partners (customers, suppliers, distributors ...) as well as to reduce their dependence on them. In addition, maintaining more social ties allow SME CEOs not only to better sell their products and reduce some costs, particularly those related to information search, decision-making, trading but to achieve their objectives in term of performance.

H1: SMEs increases their performance when their CEOs are supported by a wider network of contacts.

If managers can use their personal network, it does not mean that all can have the same chances of making their company more efficient. It depends on the quality of their relationships. It is possible that a weak network can significantly reduce the chances of the CEO to make more efficient its business but if this network is very strong and effectively coordinated it can contribute significantly to the performance of the SME.

Some studies showed the existence of a positive relationship between individual's professional success and the quality of their social ties. For example Carolis et al. (2009, p. 530) argue that "individuals with close ties to universities, perhaps through alumni associations, may develop relationships with researchers and thus have access to information about emerging technologies that can be commercialized. These individuals have then early access to promising technologies before this becomes public knowledge".

Lin (1986) found that people who are the most connected are often better placed, better paid and more readily promoted. Ireland, Tihanyi and Webb (2008) postulated that the manager's capability to develop an effective political network in emerging countries can be a key success factor to the company's performance.

Some of the difficulties faced by managers in these countries require the intervention of a well placed person to unlock a project or to obtain an approval based on strong social ties. Through trust building, these ties enhance directly the 
firm performance by transferring information and join problem solving arrangements (UZZI, 1997).

However, all portfolios of personal relationships are not equal. There are probably many types of networks for managers but not all of them lead to the same returns of resources. Some CEOs' portfolio is dominated by weak ties and other with strong ties.

In Moroccan textile industry, having many friends in high places can help to find subcontracting deal in European countries and to export easily final products. Another effect of having close tie with people in high place on performance is one that passes through innovation.

As a process that involves social interaction that is formal or informal, SME innovation can be significantly influenced by the CEO's friends working within the public research programs in particular through the sharing of ideas and information on new products, costs reducing search, reducing costs of negotiation and decision.

H2: SMEs increases their performance when their CEOs are supported by a greater number of people in high places.

The connection between the CEO's social capital and SME access to external resources

The social capital is a specific asset likely to provide a comparative advantage in a production unit. The concept expresses the fact that the expenditure of time, effort, money and other goods and services in relational activities is not a particular form of recreation but an investment that participates in the production and can be a source of profit.

According to Gulati et al. (2000), Mcevily and ZAHEER (1999) social capital is an important source for the creation of the inimitable value-generating resources that are inherent in a firm's network of relationships. These external resources are very useful for the development of new products, to increase market share and improve SME performance.

For CEOs of these companies, the external resources that are particularly the most important strategically are information (Keh, et al., 2007, CHOLLET; 
GERAUDEL, 2009) for identification of new opportunities and the funding (BRUSH, et al., 2002).

Information is widely regarded as decisive for the competitiveness and the adaptability of SMEs. Even if they are highly demanded by these companies, relevant information is scarce, expensive and not easily accessible. As some studies have shown, its management process in SMEs is poorly developed: the collection, analysis and dissemination of information often gravitate only around the manager (BRUSH, 1992).

To have the latest information, he uses his personal and informal sources which are easily accessible and often perceived as being more credible. These sources allow an immediate verification of the collected information.

With his relationships, the CEO has the advantage of obtaining information corresponding to a specific request where impersonal sources provide more general information. Therefore, the size of his network of relationships is not without effect on the information to which he may have access.

According to the extent of his network of contacts, he may be favored by a privileged access to valuable information. He may have also access to this information more quickly than others who do not have a wider network of relationships.

H3: SMES CEOS are better informed when they are supported by a wider network of relationships

According to GRANOVETTER (1973) networks have various sizes and have a stronger or weaker links. Weak ties allow more that the strong ties an individual to leave the relational context in which he is inserted and give access to new contacts and renewed information. Strong ties are generally more frequent, versatile and intimate than weak ties, but they serve to build bridges between networks.

Individuals with weak ties are more likely to move in different circles and have access to information different from those we receive. So the weak ties carry more fresh and unique information than the strong ties in which often circulate redundant information. This distinction between strong and weak ties facilitates the understanding the impact of the social ties on access to information resources. A 
CEO has access to the information he needs if he develops and maintains contacts with people to whom he is emotionally attached.

H4: SMES CEOs are the better informed when they are supported by more weak ties.

In Morocco as in most countries of developing countries, access to bank credit is mentioned as one of the major constraints to entrepreneurship. Several studies show that these constraints affect particularly SMEs (WORLD BANK, 2006; IMF, 2004).

Access to finance is often described as one of the main barriers faced by SME CEOs who invest personal capital which is not often enough. SMEs are considered risky by financial institutions because of the lack of information on the reimbursement capabilities and weak guarantees. Shareholding is limited and instruments of longterm financing for SMEs are lacking.

Among the solutions proposed in the literature, there are social relationships which are discussed for nearly two decades as an alternative to credit constraints (NAHAPIET; GHOSHAL, 1998). It can reduce the intensity of the financial problems that are likely to jeopardize the company's future and allows the CEOs to use their personal relationships to mobilize funds for their company.

According to Wu and Choi (2004), Guiso, et al. (2004), Uzzi (1999), it can reduce particularly the degree of information asymmetry in the credit market and is likely to facilitate the SMEs access to bank credit. Uzzi (1977) have shown that interpersonal relations between the banker and the entrepreneur have positive effects on credit conditions. But this cannot happen without trust, which can be more interesting than information.

The trust between the banker and CEO has a positive impact on the credit conditions as well as the level of risk assumed by the CEO by allowing exchanges that cannot be realized within the framework of formally organized markets (FERNARY, 1999).

This interpersonal trust which describes the relational dimension attaches considerable importance to the belief in the good intentions and reciprocity of each party. CEOs that are closely related to their bankers by strong interpersonal 
relationships can have easier access to financial resources at lower cost through interpersonal trust.

H5: Strong ties provide better access to financial resources than weak ties.

Figure 1 presents the model of SME CEO's social network and its impact of performance and access to external resources. Social network is represented by its dimensions identified in the literature: Size of the network, its ties (nature), and the quality of the social ties.



Figure 1: The conceptual model

\subsection{Sample and data collection}

The study focuses on a sample of 112 Moroccan SMEs located on the Marrakech, Casablanca and Kenitra axis. Sampling criteria are generally (a). Belonging to the textile industry where SMEs are facing a more competitive pressure since the arrival of European and Chinese competitors who have more resources. To overcome this challenge, most of them are intensively using their social capital. (b) The availability of the company's CEO to give us the address of their colleagues.

Without a concise database, we were obliged to collect data required for our empirical analysis through a survey of CEOs. Some information on these SMEs was collected from the Chamber of Commerce and Industry of Rabat and from AMITH (Moroccan Association of Textile and Clothing industry). 
The survey was conducted between June-August 2015 and based on the interview technique guided by questionnaire. In developing the questionnaire, we conducted a pre-exploratory survey. Subsequently, a survey questionnaire was developed, validated and pre-tested in order to check the plausibility of the research propositions.

The initial version of the questionnaire was pre-tested with four people familiar with the topic and the issue. This allowed us to review the ambiguous aspects of the questionnaire and to withdraw issues considered redundant or irrelevant to the verification of the research propositions.

\subsection{Operational Measures}

\subsubsection{Dependent variables}

Organizational performance, access to information resources and the quality of access to bank financing are our dependent variables evaluated on six point scales. In the context of SMEs, the perceptual measure which is frequently used as objective information is not easily accessible.

The organizational performance can be measured in different ways, but in this study we used three perceived qualitative indicators: profitability, turnover and reputation of the company in relation to the competition. Each indicator was measured through a 5 points ordinal scale ranging from 1 (much less) to 5 (much higher). Access to information resources was measured by classifying into four categories the information that is most important for SMEs: competition, technology, legislation and business opportunities.

The quality of information gained was measured through indicators used by O'reilly (1982): the early access (at the right time), the relevance (compared to needs) and the exclusivity. Each indicator is measured through a 5 points ordinal scale ranging from 1 (very little relevance - early-exclusive) to 5 (very relevant- early - exclusive).

The quality of access to bank financing was measured through two following criteria: the speed of obtaining the benefits and the ease of execution of the operations that take place. The following question was asked: "In general, how would you rate the quality of all the services that are offered by your bank?" Answers vary between 1 (very little fast-easy) to 5 (very fast-easy). 


\subsubsection{Independent variables}

The size of the network was measured by drawing up a list of eight categories of business relationships: links with senior officials of banks, links with senior officials of the economic development agencies, links with senior officials of the public administration, links with other CEOs, links with suppliers, links with customers, with lawyers or engineers.

But to measure social ties in this study, respondents have been asked to select among these eight categories of links which provide them moral or material support in their business. The size of relational network of each CEO is equal to the number of categories of links he has selected. The social ties were measured by asking respondents to specify the nature of the relationship they had with each business relationships they have selected.

Several authors (LIN 1995; BATJARGAL, 2001) found that links with close friends, spouses and parents relatives are strong ties and relationships with distant relatives, old friends and acquaintances are weak ties. The quality of social ties was considered as links with the people in high places, senior officials of banks and economic development agencies, officials of the public administration and other CEOs.

\subsection{Analysis and Results}

To answer to the research questions, we analyze each hypothesis. The relationship between the CEO social ties and the SME performance is not neutral. Statistical significance shown in the first part of the table I is indicated at the $p^{* *}<$ $0.01, p^{*}<0.05$. So the first hypothesis that predicted that SMEs increases their performance when supported by CEOs' wider network of contacts is confirmed.

Analysis of the results in the Table 1 indicate the existence of a strong, positive and significant link between the variable "size of relational network "and the three dimensions of organizational performance (reputation, profitability and turnover). The second hypothesis is partially confirmed. It predicted that SMEs increase their performance when their CEOs are supported by a greater number of people in high places. 
However, the correlation with "profitability" variable is not significant. The results in the Table 1 indicate the existence of a strong, positive and significant link between the variable "links with people in high places" and these two variables "reputation" and "turnover".

Table 1: Correlations between the characteristics of the SME CEO's relational network and performance indicators

\begin{tabular}{|l|l|l|l|}
\hline & Reputation & Profitability & Turnover \\
\hline Size of relational network & $0.61^{\star \star}$ & $0.58^{\star}$ & $0.69^{\star}$ \\
\hline $\begin{array}{l}\text { Relationships with people in } \\
\text { high places }\end{array}$ & $0.65^{\star \star}$ & $0.23^{\star}$ & $0.57^{\star}$ \\
\hline \multicolumn{2}{|c|}{$\left(\mathrm{p}^{\star \star}<0.01 ; \mathrm{p}^{\star}<0.05\right)$}
\end{tabular}

We distinguished four categories of information that SMEs CEOs have access to: the information on competition, technology, legislation and business opportunities. The factorial analysis performed successively on each of these categories provided one single factor. The reliability analysis performed on these factors has provided evidence of satisfactory internal consistency between 0.71 and 0.82 .

The third hypothesis is partially confirmed. It predicted that SME CEOs have access to external information when supported by a wider network of relationships. Statistical significance shown in the second part of the Table 2 is indicated at the $p^{*}$ $<0.05 ; \mathrm{p}^{\star \star}<0.01$

The results (in the Table 2) indicate the existence of a strong, positive and significant link between the variables "size of the relational network" and "access to information on the competition and business opportunities". However, the correlations with the variables "access to information on technology" and "access to information on legislation» are not significant.

This finding can be explained by the fact that the first two categories of information circulate orally and informally through social relations and direct interpersonal communication. In the other hand, the two first categories of information flow well through informal contacts but also and especially through formal sources such as fairs, newspapers, journals, government agencies, etc. The fourth hypothesis is not confirmed.

It predicted that CEOs have better access to information resources when supported by more weak ties is not corroborated. The results (in the Table 2) 
INDEPENDENT JOURNAL OF MANAGEMENT \& PRODUCTION (IJM\&P)

http://www.ijmp.jor.br

v. 9, n. 1, January - March 2018

ISSN: 2236-269X

DOI: 10.14807/ijmp.v9i1.670

indicate the existence of any significant and positive link between the variable "weak ties" and the variables related to the access to four categories of information.

Table 2: Correlations between the characteristics of the SME CEO's relational network and the access to information resources

\begin{tabular}{|l|c|c|c|c|}
\hline & $\begin{array}{l}\text { Information } \\
\text { on competition }\end{array}$ & $\begin{array}{l}\text { Information } \\
\text { on legislation }\end{array}$ & $\begin{array}{l}\text { Information } \\
\text { on technology }\end{array}$ & $\begin{array}{l}\text { Information of } \\
\text { business } \\
\text { opportunities }\end{array}$ \\
\hline Size of relational network & $0.53^{*}$ & 0.33 & 0.21 & $0.55^{*}$ \\
\hline weak ties & 0.17 & 0.29 & 0.19 & 0.23 \\
\hline
\end{tabular}

The fifth hypothesis is confirmed. It predicted that SME CEOs strong ties with his banker provide better access to financial resources than weak ties. The results ( in the Table 3) indicate that CEOs who have strong ties rather than weak ties with their bankers get faster access and more easily services from their banks. The degree of significance of the results is excellent.

Table 3: Test of mean difference between SME CEOs with strong and weak ties with their bankers

\begin{tabular}{|l|l|l|l|l|}
\hline \multicolumn{2}{|c|}{ Nature of the link with bankers } & Weak ties & Strong ties & significance \\
\hline $\begin{array}{l}\text { Indicators of } \\
\text { access to } \\
\text { financial } \\
\text { resources }\end{array}$ & $\begin{array}{l}\text { Fast execution of } \\
\text { operations }\end{array}$ & 3.31 & 4.01 & 0.001 \\
\cline { 2 - 5 } & $\begin{array}{l}\text { Ease of obtaining } \\
\text { services }\end{array}$ & 2.49 & 3.67 & 0.001 \\
\hline
\end{tabular}

Table 4: We combine all the results, the hypothesis and the different dimensions of social network

\begin{tabular}{|l|l|l|}
\hline Dimensions of social capital & Hypothesis & Results \\
\hline Size of relational network & $\begin{array}{l}\text { A wider network of contacts enables: } \\
\text { H1: organization better performance } \\
\text { H3: better access to information } \\
\text { resources }\end{array}$ & H1 is confirmed \\
\hline Nature of interpersonal ties & $\begin{array}{l}\text { H4: when more links are weak, } \\
\text { better would be the access to } \\
\text { information resources } \\
\text { H5: strong ties allow better access } \\
\text { financial resources than weak ties }\end{array}$ & H4 is not confirmed \\
\hline Quality of interpersonal ties & $\begin{array}{l}\text { H2: when CEO has more links with } \\
\text { people in high places, better would } \\
\text { be the performance of the company. }\end{array}$ & H2 is partially confirmed \\
\hline
\end{tabular}

\section{DISCUSSION}

The implications of this study are at two levels. First, it identifies the characteristics of the Moroccan CEO's network and their relations to the SMEs performance. While much work has focused on the impact of the network size on performance, our results show that the nature and quality of relationships are a key factor in the success of Moroccan SMEs. 
These results support the existing theoretical arguments on the links between social network and performance (GRANOVETTER 1973; BURT 1983; LIN; DUMIN 1986, SCHMIDT 2013, SHAH et al 2017). The results also confirm that the dimensions of social network discussed in the study do not have the same influence on SMEs performance.

If the size of relational network is strongly related to the organizational performance, the greater number of people in high places does not have the same level of correlation because of the profitability variable. This support HANSEN, et al. (2001) approach which consider that the heterogeneity of network is not always desirable.

Second, the study proposes to consider Moroccan SMEs access to external resources as a result of CEOs' social network efforts. The result on access to information about the competition and business opportunities when supported by a wider network of relationships confirmed the previous works of Adler and Kwon (1998), Brush (1992).

It highlights the importance of developing relational capabilities in the SME management's strategies as suggested by Fillion (1992). The correlations between the variables "access to information related to technology and legislation" with the size of the network have not been.

The results do not support the hypothesis that many weak ties lead CEOs to have access to information resources because of the developed trust among the network members. It is therefore in opposition to the suggestion of Granovetter (1973), Plociniczak (2001).

In addition, findings also support the theoretical arguments of Lehman and Neuberger (2000), Uzzi (1997), Cull, et al. (2016), Hernandez-Carrion (2016) that strong ties with bankers provide better access to financial resources than weak ties. The results have also the advantage of opening new questions about the role of personal networks.

In particular, the variables such as gender and education level of the CEO, and the size of the company that have a significant effect on the access to external information. 
DOI: 10.14807/ijmp.v9i1.670

\section{CONCLUSION}

This study has highlighted the importance of Moroccan SMEs CEOs' social network on the performance of their business. For example, it showed that a wide network of relationships has a major impact on the SME CEO ability to make his business more efficient and promotes his access to more information related to competition and business opportunities.

It also showed that access to financial resources and relevant information not available in-house can be achieved by using social network which aim is to ensure the survival of the company or its development. While presenting a lack of research on this topic in the Moroccan context, the study showed the importance of using social network in the textile industry which is strongly affected by the economic crisis.

Its theoretical implication is that the social network dimensions used (size of managers' network, the nature of its network ties and the quality of this network) do not have the same influence on the SMEs performance. More specifically, social network dimensions do not allow access to all the resources desired by CEOs.

Naturally, this work has a number of limitations inherent to quantitative research. First, it's based on a sample that does not ensure the generalizability of the results to all the SMEs. The variables that represent the dimensions of social network used in the study cannot be complete. However, given the facts that this study is the first in the Moroccan context, a relatively simple model at this stage can be acceptable.

As the analysis is based only on the textile industry, it becomes necessary to extend it to all SMEs in order to test the generality of the arguments. Nevertheless, we believe that the results of the study can contribute to enrich the theory. But future research could be oriented on how actors develop their relational networks in order to achieve their business goals specifically in Morocco and how to use them effectively.

\section{REFERENCES}

ADLER, P. S.; KWON, S. W. (2002) Social capital: prospects for a new concept. Academy of Management Review, n. 27, p. 17-24.

ALDRICH, H. E.; ZIMMER, C. (1986) Entrepreneurship trough social networks. In: SEXTON D. L.; SMILOR, R. W. (éds), The art and science of entrepreneurship, Cambridge, Belinger, p. 3-23. 
ALDRICH, H. E.; DUBUNI, P. (1991) Personal and Extended Networks Are Central to the Entrepreneurial Process, Journal of Business Venturing, v. 6, p.305-313.

\section{ALIZADEH, Y. (2000) Unravelling small business owner/manager's networking} activities. http://www.sbaer.uca.edu/research/2000/icsb/pt1/056ali.pdf.

BAKER, W. (1990) Market networks and corporate behavior. American Journal of Sociology, n. 96, p. 589- 625.

BAMBERGER, I. (1979) Développement et croissance des entreprises: un cadre de référence théorique pour un projet de recherche concernant les petites et moyennes entreprises, cahiers stratégies et organisations, IGR Rennes, Sept, N²

BOURDIEU, P. (1980) Le sens pratique, Paris: Editions de Minuit

BRASSIER-RODRIQUES, C.; BRASSIER, P. (2009) Le réseau social du dirigeant de petite et moyenne entreprise : un outil stratégique au service de sa communication, in Le grand livre de l'économie PME, Gilles Lecointre (Dir.), Gualino, Paris, p. 171-189, January 2010.

BURT, R. S. (1992) Structural Holes: The Social Structure of Competition. Cambridge, MA: Harvard University Press.

BURT, R. S. (1997) "The contingent value of social capital". Administrative Science Quarterly, 42, pp 339-365.

BRUDERL, C. G.; PREISENDORFER, P. (1998) Network support and the success of newly founded businesses, Small Business Economics, n. 10, p. 213-225

BRUSH, C. G.; EDELMAN, L. F.; MANOLOVA, T. S. (2002) The impact of resources on small firm internationalization. Journal of Small Business Strategy, v. 13, n. 1, p. 1-17

BRUSH, C. G. (1992) Research on Women Business Owners: Past Trends, a New Perspective and Future Directions. Entrepreneurship Theory and Practice (Summer), p. 5-30.

CAROLIS, D. M. D.; LITZKY, B. E.; EDDLESTON, K. A. (2009) Why Networks Enhance the Progress of New Venture Creation: The Influence of Social Capital and Cognition. Entrepreneurship Theory and Practice (March), p. 527-545.

COLEMAN, J. S. (1988) Social capital in the creation of human capital. American Journal of Sociology, n. 94, p. 95-120.

CHOLLET, B. ; GERAUDEL, M. (2009) Quand la PME bénéficie du bouche à oreille: l'effet combiné de la personnalité du dirigeant et de son réseau personnel. Management International, v.13, n. 4, p. 47-64.

CULL, R.; GAN, L.; GAO, N.; XU, L. C. (2016) Social Capital, Finance, and Consumption: Evidence from a Representative Sample of Chinese Households (October 24). World Bank, Policy Research Working Paper No. 7873. Available at SSRN: https://ssrn.com/abstract=2867654

DOH, S.; ZOLNIK, E. (2011) Social capital and entrepreneurship: An exploratory analysis, African journal of business management, v. 5, n. 12, p. 4961-4975

DUBINI, P.; ALDRICH, H. (1991) Personal and Extended Networks Are Central to the Entrepreneurial Process, Journal of Business Venturing, v. 6, n. 5, p. 305 
FALEYE, O.; KOVACS, T.; VENKATESWARA, A. (2014) Do better-connected CEOs innovate more? Journal of Financial and Quantitative Analysis, v. 49, n. 5-6), p. 1201-1225.

FANG, Y.; FANCIS, B.; IFTEKHAR, H. (2012) More than Connectedness Heterogeneity of CEO Social network and Firm value, Available at https://ssrn.com/abstract=2172767 or http://dx.doi.org/10.2139/ssrn.2172767

FERNARY. M. (1999) Confiance et accumulation du capital social dans la régulation des activités de crédit, Revue Française de Sociologie, XL-3, p. 559-586.

FILLION, L. J. (1991) Vision et relations : clefs du succès de l'entrepreneur, Les éditions de l'entrepreneur, Montréal, p. 272.

GRANOVETTER, M. (1973) The strength of weak ties. American Journal of Sociology, v. 78, p. 1360-1380.

GOSHAL, S.; PETER, M. (1996) Bad for Practice: A Critique of the Transaction Cost Theory, Academy of Management Review, n. 21, p. 13-47.

GUISO, L.; SAPIENZA, P.; ZINGALES, L. (2004b) The Role of Social Capital in Financial Development, American Economic Review, n. 94, p. 526-556.

GULATI, R.; NOHRIA, N.; ZAHEER, A. (2000) Strategic networks, Strategic Management Journal, v. 21, n. 3, p. 203-215.

IRELAND R. D.; TIHANYI, L.; WEBB, J. W. (2008) A Tale of Two Politico-Economic Systems: Implications for Entrepreneurship in Central and Eastern Europe.

Entrepreneurship Theory and Practice (January), p. 107-130.

JOHANNISSON, B. (1986) Network strategies: management technology for entrepreneurship and change, International Small Business Journal, v. 5, n. 1, p. 19-30

KEH, H. T.; NGUYEN, T. T. M.; NG, H. P. (2007) The effects of entrepreneurial orientation and marketing information on the performance of SMEs. Journal of. Business Venturing, n. 22, p. 592-611.

KIRCHMAIER, T.; STATHOPOULOS, K. (2008) From Fiction to Fact: The Impact of CEO Social Networks, Corporate Governance at LSE, Discussion Paper N 608.

LEHMAN, E.; NEUBERGER, D. (2001) Do lending relationships matter? Evidence from Bank Survey Data in Germany, Journal of Economic Behavior and Organization, n. 45, p. 339-359

LIN, N. (1986) Conceptualizing social support. In: LIN, N.; DEAN, A.; ENSEL, W. (Eds.), Social support, life events, and depression, p. 17-30 New York: Academic Press.

LIN N. (1995) Les Ressources Sociales: Une Theorie du Capital Social. Revue. Francaise de Sociologie, v. 36, n. 4, p. 685-704.

LUTHANS, F.; STEWART, T. (1977) A general contingency theory of management, Academy of Management Review, April, p. 181-195

MCEVILY, B.; ZAHEER, A. (1999) Bridging ties: a source of firm heterogeneity in competitive capabilities. Strategic Management Journal, n. 20, p. 1133-1156. 
MIZRUCHI, M. S. (1996). What do interlocks do? An analysis, critique, and assessment of research on interlocking directorates. Annual Review of Sociology, n. 22, p. 271-298.

NAHAPIET, J.; GHOSHAL, S. (1998) Social capital, intellectual capital, and the organizational advantage. Academy of Management Review, n. 23, p. 242-266.

O'REILLY, C. A. (1982) Variations in decision makers use of information's sources. Academy of Management Journal, v. 25, n. 4, p.756-771.

PENNINGS, J. M.; GOODMAN, P. S. (1977). Toward a workable framework. In: GOODMAN, P. S.; PENNINGS, J. M. (Eds.), New perspectives on organizational effectiveness (pp. 146-184). San Francisco: Jossey-Bass.

PORTES, A. (1998) Social capital: its origins and applications in modern sociology, Annual Review of Sociology, n. 24, p.1-24.

REYNOLDS, P. D. (1991) Sociology and Entrepreneurship: Concepts and Contributions. Entrepreneurship: Theory \& Practice, v. 16, n. 2, p. 47-70

ROXAS, B. G. (2008) Social capital for knowledge management: The case of small and medium-sized enterprises in the Asia-Pacific Region, Asian Academy of Management Journal, n. 13, p. 57-77.

SEIBERT, S. E.; KRAIMER, M. L.; LIDEN, R. C. (2001) A social capital theory of career success. Academy of Management Journal, v. 44, n. 2, p. 219-237.

SHAH, N. P.; PARKER, A.; WALDSTROM, C. (2017) Examining the Overlap, Individual Performance Benefits of Multiplex Relationships, Management communication Quaterly, v. 31, n. 1, p. 5-38

SURIN, E. F.; HALIL N. H. A.; EDWARD, O. T. (2015). The Comparative Analysis of Gender and Social Network among Malay SMEs Entrepreneurs in Malaysia. Journal of Economics, Business and Management, v. 3, n. 7.

http://dx/doi.org/10.7763/JOEBM.2015.V3.272

TANGEGEAOUI, S. (1993) les entrepreneurs marocains: pouvoir, société et modernité. Karthala, Paris

UZZI, B. (1997) Social structure and competition in interfirm networks: The paradox of embeddedness. Administrative Science Quarterly, n. 42, p. 35-67.

WEI-PING, W.; Choi, W. L. (2004) Transaction cost, Social capital and firm's synergy creation in Chinese Business Networks: An Integrative Approach, in Asia Pacific Journal of Management, v. 21, p. 325-343. 